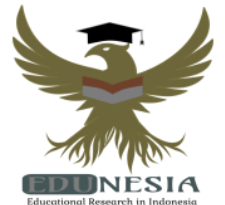

\title{
Emotional Geographic Conditions in the COVID-19 Era at SMAN 1 Pagaden
}

\author{
Ahmad Nurdin'1, Hani Chaerunnisa2 ${ }^{2}$, Anwar Shidiq Santoso ${ }^{3}$ \\ ${ }^{1}$ Teacher Geography, SMAN 1 Pusakanagara, Indonesia \\ 2,3Teacher Geography, SMAN 1 Pagaden, Indonesia \\ ${ }^{1}$ Corresponding Email: ahmadnurdin450@gmail.com , Phone Number: 0898 xxx xxxx
}

Article History:

Received: August 31, 2021

Revised: Sept 15, 2021

Accepted: Sept 19, 2021

Online First: Sept 29, 2021

\section{Keywords:}

Geography of Emotions,

Students and Teachers,

Pandemic.

Kata Kunci:

Geografi Emosi,

Siswa dan Guru,

Pandemi.

\section{How to cite:}

Nurdin, A., Chaerunnisa, H., \& Santoso, A.S. (2021). Emotional Geographic Conditions in the COVID-19 Era at SMAN 1 Pagaden. Edunesia: Jurnal Ilmiah Pendidikan, 2 (3): 677-684.

This is an open access article under the $C C-B Y-N C-N D$ license
Abstract: Facing the COVID-19 pandemic, many habits or routines have changed. Activity restrictions are one of the efforts to prevent the spread of this pandemic. However, adapting to new habits is not an easy thing to do. As an adaptation to a new habit, temporary learning must be done online. Teachers and students experience many obstacles in doing online learning. So that a lot of research has been carried out to compile an effective and efficient online learning. However, research rarely reveals the emotional condition of teachers and students during a pandemic. Using descriptive qualitative methods, this study will reveal the geographic conditions of emotion at SMAN 1 Pagaden. The data were obtained through direct and indirect interviews, direct interviews were conducted with the teacher, while for students, a questionnaire was distributed using google form. The data is reduced and analyzed to get answers about the emotional condition of teachers and students at SMAN 1 Pagaden in the face of the pandemic. All data obtained after being analyzed will get solutions and ways to overcome the problems faced during this pandemic. With a research foundation that refers to Hargreaves' thoughts on the geography of emotions that limit questions to physical, socio-cultural, moral, professional and political elements.

Abstrak: Menghadapi pandemi COVID-19 banyak kebiasaan atau rutinitas yang berubah. Pembatasan aktivitas merupakan salah satu upaya untuk mencegah penyebaran pandemi ini. Tetapi, adaptasi kebiasaan baru bukan suatu hal yang mudah untuk dilaksanakan. Sebagai adaptasi kebiasaan baru, pembelajaran sementara harus dilakukan secara daring. Guru dan siswa mengalami banyak kendala dalam melakukan pembelajaran daring. Sehingga banyak penelitian yang dilakukan untuk menyusun sebuah pembelajaran daring yang efektif dan efisien. Namun jarang penelitian yang mengunggkapkan kondisi emosi guru dan siswa dimasa pandemi. Menggunakan metode kualitatif deskriptif, penelitian ini akan mengungkapkan kondisi geografi emosi di SMAN 1 Pagaden. Data diperoleh melalui wawancara langsung dan tidak langsung, wawancara langsung dilakukan kepada guru sedangkan untuk siswa menggunakan angket yang disebar menggunakan google form. Data direduksi dan dianalisa untuk mendapatkan jawaban tentang kondisi emosi guru dan siswa di SMAN 1 Pagaden dalam menghadapi masa pandemi. Semua datadata yang diperoleh setelah dianalisa akan mendapatkan solusi dan cara mengatasi masalah yang dihadapi selama pandemi ini. Dengan landasan penelitian yang mengacu kepada pemikiran Hargreaves tentang geografi emosi yang membatasi pertanyataan kepada unsur fisik, sosial budaya, moral, profesional dan politik. 


\section{A. Introduction}

The COVID-19 pandemic situation has forced teachers to be able to innovate not only in teaching methods, but also in using appropriate technology to carry out distance learning. Teachers and students must carry out the Learning at Home process as an effort to prevent the spread of COVID-19. Of course, as a professional, the teacher must be able to adapt to the conditions of Studying at Home by seeking various literacy and research related to distance learning. As stated by Huproni (2020) "teachers' pedagogical abilities must continue to be developed through research based on learning models".

Various literatures tell of the impact of the COVID-19 pandemic which not only affects health. But it has influenced other aspects such as economics, psychology, social interaction, and the education system. Orgilés et al., (2021) stated that the COVID-19 pandemic has brought about major changes in the lives of children and adolescents. School closures have changed their academic routine, social distancing has limited their social relationships with their family members, and the closure of public spaces has changed their free time, limiting it to their homes."

The psychological condition of students is greatly affected by this pandemic, they are forced to carry out Studying at Home as an effort to prevent the spread of the COVID19 pandemic. In mental development, students need a lot of interaction and exploration to be able to find their identity. They must be experiential rich, not passive, and interactive. In order to build an understanding that is imaginative, integrative, intact, and environmentally insight.

Student experience is very much needed as an effort to strengthen the character of love for the homeland, as expressed by Chaerunnisa, (2019) that "strengthening the character of love for the homeland in students can be done by elaborating their experiences into knowledge and manifested in actions that reflect a sense of love." homeland, have a good insight into the archipelago, and manifest gratitude to the Creator. So it does not only focus on mere theoretical knowledge, but needs to be supported by empirical experiences in the field".

Another study of the correlation between psychological conditions and the environment is expressed by Hargreaves (2001) who says that emotional geography as: "spatial patterns and experiences of closeness and/or gaps in human interactions and relationships that help create, configure, and color feelings and emotions. what we experience about ourselves, our world, and each other".

Sukmayanti, et al., (2021) stated "the atmosphere of learning at home and face-toface learning at school will of course provide a different experience. The learning atmosphere makes students interact directly with the teacher and their friends, students can gather and joke when learning is carried out at school. Students will find it easier to express various expressions during face-to-face learning. In the interactions carried out by students in the classroom, they teach various things such as conflict management, how to communicate, learning to share, learning to behave according to norms, adapting to the environment, to overcoming the problem of attraction to the opposite sex. Psychological problems faced by students and teachers during the pandemic are rarely disclosed in scientific research.

$52.8 \%$ of students at SMAN 1 Pagaden stated that online learning was effective. Meanwhile, $49.8 \%$ of students at SMAN 1 Pagaden stated that online learning had not been effective. Students stated that the learning carried out was not effective because of the many tasks given and the delivery of material that could not be understood so that it affected 
students' saturation in learning online. Student responses stating boredom in online learning greatly affect psychology which has an impact on decreasing student learning motivation.

There have been many studies that reveal various learning innovations during the pandemic. However, this study will discuss more deeply about the emotional conditions of students and teachers of SMAN 1 Pagaden in dealing with the COVID-19 pandemic situation. With reference to the theoretical basis put forward by Hargreaves about emotional geography. By asking research questions "how are the emotional conditions of teachers and students in dealing with the COVID-19 pandemic and what are the efforts made by teachers and students in dealing with the COVID-19 pandemic".

\section{B. Method}

This research is a descriptive qualitative. With reference to the theoretical basis put forward by Hargreaves about emotional geography. By asking research questions "how are the emotional conditions of teachers and students in dealing with the COVID-19 pandemic and what are the efforts made by teachers and students in dealing with the COVID-19 pandemic". Data were obtained through interviews with students and teachers of SMAN 1 Pagaden. As the research sample, the students of Class X and Class XI were determined, totaling 117 respondents from 1221 population of SMAN 1 Pagaden students. Participants from the teacher's side were 3 people who represented the MIPA group teachers, Social Studies group, and the Religious Mapel group. Interviews with students used a questionnaire while the teachers were interviewed directly to get answers to research questions regarding emotional conditions during the COVID-19 pandemic. Furthermore, the data obtained is reduced and validated for analysis without using statistical or mathematical techniques. The research was conducted from February to April 2021.

\section{Result and Discussion}

The basis for conducting analysis through narrative geography of emotions is emphasized by Albin-Clark (2018), Hargreaves (2001) and Olson (2015) (in Taloko, et al., 2020), by observing patterns of intimacy and/or gaps in human interaction. Such patterns come to the surface due to the construction of emotions that arise in human relationships. The realization of emotions, of course, is recorded and stored in the form of experiences in each person's mind. The discussion based on emotional geography which is divided into physical geography, sociocultural geography, moral geography, professional geography and political geography is presented below.

\section{Physical Geography: "The wifi phenomenon and stingy neighbors"}

Taher (2017) explains that "physical geography is seen as an objective science because it is based on human behavior (Subjectivist approaches)". During Studying at Home, student activities become passive because space is limited to reduce crowds. With these conditions students are more sensitive to their environment. Many things were observed by students as expressed by respondents about what had changed from the surrounding environment. Several respondents explained that they observed the condition of their neighbors who changed professions from sheep farmers to duck farmers. The interesting thing expressed by respondents was when they saw the change in the attitude of neighbors who became stingy and selfish as an effort to survive in this pandemic condition. As stated by Denzin, 1984 (in Taloko, et al., 2020) which states "differences in the dimensions of space and time 
have the potential to cause misunderstandings that require emotional understanding between one another.

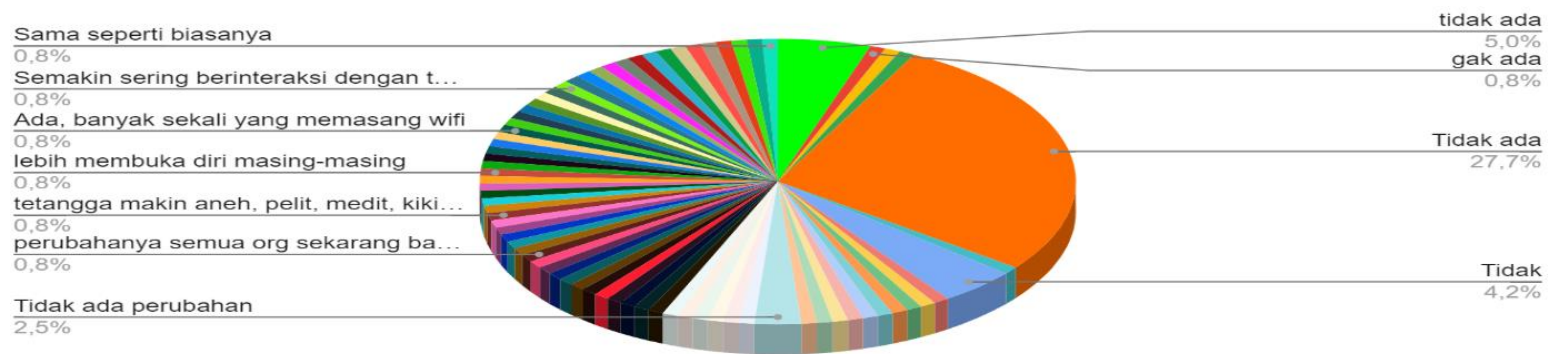

Figure 1. Change of attitude

Online learning has created a new phenomenon in society. Based on the diagram above, it is known that about $0.8 \%$ of respondents observed that many in the neighborhood around their homes installed wifi networks. The purpose of installing wifi is as a supporting tool for carrying out Study at Home. Respondents said that by installing wifi they could save the cost of buying internet quota. The use of wifi is seen as more efficient and the internet network is more stable.

\section{Sociocultural Geography: "relations with family are getting better"}

Hutauruk, \& Mursid, (2019) argues that "the uniqueness of regional culture is relevant to the object of study of cultural geography. In cultural geography, the differences between the results of human cultivation and the unique way of life of humans in each region can be analyzed according to their distribution and uniqueness. Students and parents get plenty of time to interact. Students' relationships with parents become more open, usually they can gather and joke with their families in a limited time. The hectic routines that students and parents have to go through make it rare for them to talk so that students are more comfortable expressing various problems to their friends or other relatives.

The COVID-19 pandemic has brought about better conditions in terms of relationships between families, students are more open to express various expressions (either sad or happy conditions) to their parents. Discussions that were previously not well established between family members turned out to have another impact, namely the advice given by parents was well received along with improving relations between family members. The advice given by parents provides new motivation and enthusiasm for students in learning.

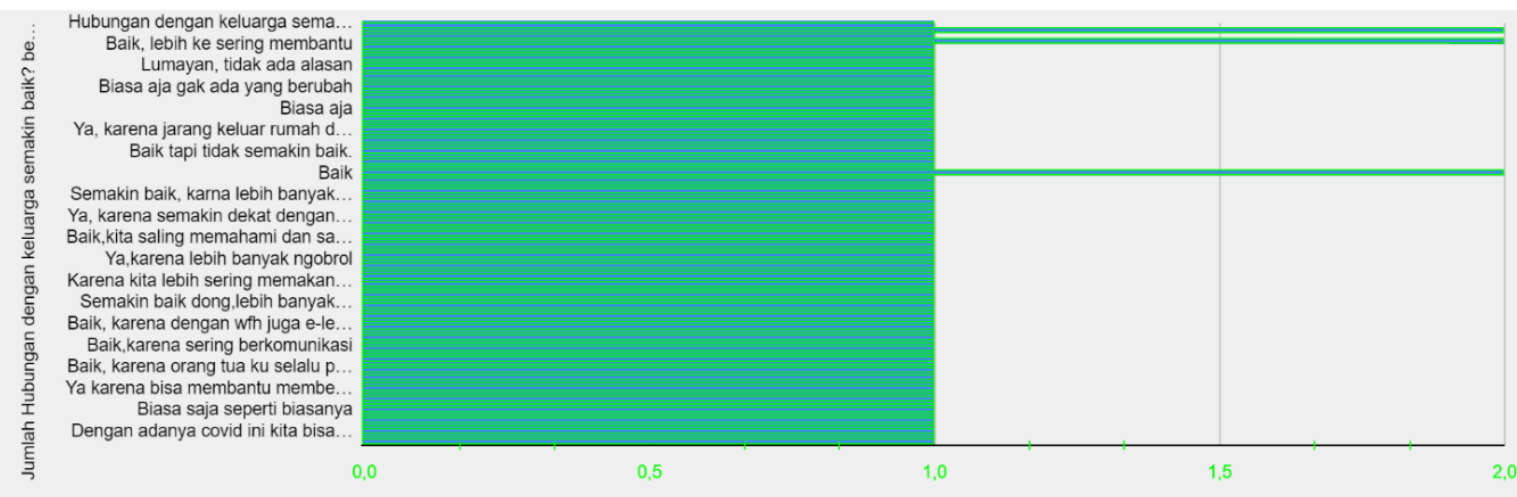

Figure 2. Family Relationship 
Studying at home conditions allow students to help their parents with their work, from cleaning the house to helping their family business. The habit of students helping their mothers to take care of the household makes students enjoy the work of helping their parents more. Even an interesting expression was expressed by one respondent who said that he felt $75 \%$ was suitable to be a housewife and $25 \%$ still hoped to be a student.

Research conducted by Dani \& Mediantara, (2020) revealed that "changes that occur in social communication are seen and felt when the COVID-19 outbreak hits the world, with transmission through humans, making communication patterns out of function, by using too many assistive devices." as an intermediary, so that conversations, gestures, conversational logic often experience new misperceptions and assumptions about symbol communication.

\section{Moral Geography: "Webinars and plummeting performance"}

Moral geography according to Taloko, et al (2020) that what is meant by moral geography "refers to the proximity and/or gaps that occur due to differences in goals and desires to achieve professional practice achievements". In this study, several respondents were disappointed with the learning outcomes obtained during this pandemic. They complained about the declining performance as a result of the delivery of the material delivered by the teacher could not be understood properly and tended to study at home only in the nature of giving assignments without explaining the material first. Learning that must be done online creates obstacles for most teachers, especially teachers who are in the old age range. They face learning situations that involve technology while the understanding and mastery of technology for senior teachers is very low. This has an impact on the delivery of material which is only task assignment. Sulistyawati's findings (2020) reveal "the consequences of student behavior who experience a decrease in interest in learning greatly affect the decline in the grades they achieve. Both in the form of report cards, educational values, and caring values".

Research conducted by Asmuni (2020) found that "the ability of teachers is limited in using technology in online learning. Not all teachers are able to operate computers or gadgets to support learning activities, both face-to-face, and even more so in online learning. Indeed, there are some teachers who are able to operate computers, but in terms of oppression, they are limited. They are not able to access further related to the internet network, use various learning applications, make their own learning media/videos and so on". The teacher's ability to manage online learning has an effect on student learning outcomes.

Online learning that was carried out during the pandemic became the habituation of students to a new method in the teaching and learning process. Some students have adaptive abilities and good motivation to learn so that this moment is used to conduct online seminars. They become more enthusiastic in doing webinars on the grounds that they can interact with other students outside their school environment and even cross-regional and cultural interactions occur. This should be seen as a positive thing from online learning and should be passed on and conveyed to other students to build the same motivation.

\section{Professional Geography: "More familiar with technology and information"}

During this pandemic, almost all activities are carried out at home such as worship at home, working at home, shopping at home, and studying at home. Although all activities 
are carried out at home, it does not mean reducing work and learning productivity, because all these activities can still be done virtually even though the results are not so optimal. To carry out online learning, it can be done by involving technological devices.

Conditions before the pandemic, people are not used to or rigid to the use of technology and information. Since the COVID-19 pandemic, the entire community has adapted to the use of information technology such as online purchases, Studying at Home (BDR), work, seminars, and other activities. In this case, teachers and students are forced to be able to master technology well to carry out online teaching and learning routines. Thus there is a paradigm shift in the teaching and learning process. For developed countries, distance learning is not something new so that online teaching and learning activities can still be carried out effectively and efficiently.

In an interview with a geography teacher, Mr. Subrata, he revealed that he was very awkward and didn't even understand technology at all. However, this pandemic condition forces all teachers and students to be able to adapt well in online learning. Gradually, although not very proficient, Mr. Subrata was able to operate several online learning support applications such as Google Meet. A positive step from this pandemic is that people are starting to adapt to technology and information as capital to face 21st century competencies.

\section{Political Geography: "Policies that are well-targeted to tackle the pandemic"}

In an interview with one of the respondents from Class XI students, he expressed his opinion on hopes for the government to overcome this pandemic. The following is an excerpt from an interview conducted to the respondent (let's just say his name is X) "Well, how about it, all orders and prohibitions have been deployed by the government, starting from small things from wearing masks to big things such as social restrictions and lockdowns in some areas, everything has been done. with pros and cons, some people have already implemented the vaccine, and is there any change? I hope that changes, even if it's a little. The pandemic is not only a matter of public health, actually, it also depends on the social life of each community. Many prohibitions, many rules, many orders that should make things better, it's just the opposite. For now, other than trusting the government, what else are people going to do? Even if public opinion is heard, will it be appreciated and implemented? If the question is what the expectations are, it must have always been the same since the beginning of the pandemic. Because the current unrest continues, hopefully the government can quickly find a definite solution regarding this pandemic.

Respondents want this pandemic to end as soon as possible, so that they can carry out their activities as usual. They hope that schools can be opened soon, although by implementing health protocols by dividing the face-to-face learning system into two sessions. Most of the respondents felt pressured by this pandemic, therefore they hoped for good cooperation between the government and citizens so that this pandemic would end soon.

\section{Conclusion}

There are many studies on how to build understanding in learning innovation during the pandemic. But it is very rarely disclosed how the psychological impact of students and teachers during this pandemic. Through this research, there are several expressions about the emotional condition of students and teachers. As many as $12.8 \%$ of 
respondents stated that the restrictions on activities outside the home caused the relationship with family members to become more harmonious. Improved communication between family members is able to build motivation and enthusiasm for student learning.

\section{References}

Asmuni, A. (2020). Problematika Pembelajaran Daring di Masa Pandemi Covid-19 dan Solusi Pemecahannya. Jurnal Paedagogy, 7(4). doi:https:/ / doi.org/10.33394/jp.v7i4.2941

Chaerunnisa, H. (2019). Peran Geografi Dalam Menanamkan Rasa Cinta Tanah Air dan Wawasan Nusantara di SMAN 1 Pagaden. Jurnal Geografi Gea, 19 (1), hal 76-83, https://doi.org/10.17509/gea.v19i1.16411.

Dani. J.A, \& Mediantara.Y, (2020). COVID-19 Dan Perubahan Komunikasi Sosial. PERSEPSI: Communication Journal, 3 (01), hal 94-102, https://doi.org/10.30596/persepsi.v3i1.4510.

Hargreaves, A. (2001). Emotional geographies of teaching. Teachers College Record, 103(6), 1056-1080. DOI: 10.1111/0161-4681.00142.

Huproni, H. (2020). Penerapan Metode Drill and Practice Dalam Upaya Meningkatkan Hasil Belajar Pendidikan Agama. Sustainable, 3(2), 62-76. https://doi.org/10.32923/kjmp.v3i2.1424

Hutauruk, M.O.R \& Mursid, R. (2019). Esensi Geografi Budaya Dalam Pembelajaran Berbasis Teknologi Informasi Dan Komunikasi. Prosiding Seminar Nasional Teknologi Pendidikan Pascasarjana HNIMED, hal 578-583, http:// digilib.unimed.ac.id/38848/3/ATP\%2066.pdf.

Orgilés, M., Morales, A., Delvecchio, E., Francisco, R., Mazzeschi, C., Pedro, M., \& Espada, J. P. (2021). Coping Behaviors and Psychological Disturbances in Youth Affected by the COVID-19 Health Crisis. Frontiers in Psychology, 12. https:// doi.org/10.3389/fpsyg.2021.565657.

Sukmayanti, M.,Chaerunnisa, H., \& Santoso, A.S. (2021). Preliminary Diagnostic Assessment in Distance Learning at SMAN 1 Pagaden. Edunesia: Jurnal Ilmiah Pendidikan, 2 (2): 503-513. https:// doi.org/10.51276/edu.v2i2.158.

Sulistyawati. T.E (2020). Perspektif Aksiologi Terhadap Penurunan Minat Belajar Anak di Masa Pandemi. Aksiologi : Jurnal Pendidikan dan Ilmu Sosial, 1 (1), hal 33-43, http://aksiologi.pubmedia.id/index.php/aksiologi/article/view/2.

Taher, A. (2017). Babak Baru Metode Penelitian Geografi Manusia. Jurnal Sosiologi, 11 (1), hal 122, http://www.jurnal.unsyiah.ac.id/JSU/article/view/9652. 
Taloko, J. L., Putra, M. S., \& Hartanto, Y. (2020). Emotional Geographies Experienced by an Indonesian Doctoral Student Pursuing her PhD in New Zealand during the COVID19 Pandemic. Journal of International Students, 10(S3), 126-141. https://doi.org/10.32674/jis.v10iS3.3203. 